\title{
Mikroenkapsüle ve Serbest Probiyotik Kültür İlavesiyle Fonksiyonel Keçiboynuzu Pekmezi Üretimi
}

\author{
Emel ÜNAL TURHAN ${ }^{1 *}$
}

\section{Öz}

Bu çalışmada, serbest ve mikroenkapsüle probiyotik kültür ilavesiyle keçiboynuzu pekmezi üretimi gerçekleştirilmiş ve depolama koşullarının ürün kalite özellikleri üzerindeki etkisi incelenmiştir. Probiyotik keçiboynuzu pekmezi üretiminde probiyotik kültür olarak Lactobacillus. rhamnosus kullanılmıştır. Sade (kontrol grubu) ve probiyotik keçiboynuzu pekmezi örnekleri 2 farklı sıcaklıkta $\left(4^{\circ} \mathrm{C}\right.$ ve $\left.25^{\circ} \mathrm{C}\right) 30$ gün boyunca depolanmış ve keçiboynuzu pekmezi örneklerinde probiyotik canlı hücre sayısı, pH ve duyusal analizler yapılmıştır. Depolama sonunda mikroenkapsüle kültür ve serbest kültür ile üretilen pekmezlerde canlı probiyotik hücre sayısı sırasıyla $7.79 \log \mathrm{kob} / \mathrm{mL}$ ve $7.31 \log \mathrm{kob} / \mathrm{mL}$ bulunmuştur. Depolama süresinin L. rhamnosus sayısı üzerindeki etkisi serbest kültür ile üretilen örnekler için önemsiz bulunurken mikroenkapsüle kültür ile üretilmiş örnekler için istatistiksel olarak önemli bulunmuştur. Ayrıca, probiyotik hücre konsantrasyonunda, farklı depolama sıcaklıklarının önemli bir etkisi olmamıştır. Örneklerin pH değerleri üzerinde ise sadece depolama süresinin etkisinin önemli olduğu saptanmıştır. Duyusal özellikler açısından en yüksek beğeniyi kontrol grubu örneği olan sade keçiboynuzu pekmezleri alırken en düşük beğeniyi mikroenkapsüle kültür ile üretilen pekmezler almıştır. Depolama sonunda tüm pekmez örneklerinde duyusal kalite puanları düşmüştür. Ayrıca, $4^{\circ} \mathrm{C}$ 'de depolamanın pekmezin duyusal özellikleri üzerinde daha olumlu bir etkisinin olduğu saptanmıştır.

Anahtar Kelimeler: Keçiboynuzu pekmezi, Probiyotik, L. rhamnosus, Mikroenkapsülasyon

\section{The Production of Functional Carob Molasses with the Addition of Microencapsulated and Free Probiotic Culture}

\begin{abstract}
In this study, the production of carob molasses with the addition of free and microencapsule probiotic culture was carried out and the effect of storage conditions on product quality characteristics was examined. Lactobacillus rhamnosus was used as a probiotic culture in the production of probiotic carob molasses. Plain (control group) and probiotic carob molasses samples were stored for 30 days at 2 different temperatures $\left(4^{\circ} \mathrm{C}\right.$ and $\left.25^{\circ} \mathrm{C}\right)$ and probiotic viable cell count, $\mathrm{pH}$ and sensory analyses were performed in carob molasses samples. At the end of storage, the number of live probiotic cells was $7.79 \log \mathrm{cfu} / \mathrm{mL}$ and $7.31 \log \mathrm{cfu} / \mathrm{mL}$ respectively in molasses produced with microencapsule culture and free culture. While the effect of storage time on the number of L. rhamnosus was insignificant for samples produced with free culture, it was found to be statistically important for samples produced with microencapsule culture. Additionally, in probiotic cell concentration, different storage temperatures have not had a significant effect. On the $\mathrm{pH}$ values of the samples, it was determined that only the effect of storage time was important. The highest appreciation in terms of sensory properties was taken by plain carob molasses, which is an example of the control group, while the lowest appreciation was the molasses produced with microencapsule culture. Sensory quality scores decreased in all molasses samples at the end of storage. It was also found to have a more positive effect on the sensory properties of storage at $4^{\circ} \mathrm{C}$.
\end{abstract}

Keywords: Carob molasses, Probiotic, L. rhamnosus, Microencapsulation

\footnotetext{
${ }^{1}$ Osmaniye Korkut Ata Üniversitesi, Kadirli Uygulamalı Bilimler Yüksekokulu, Gıda Teknolojisi Bölümü, Osmaniye, Türkiye, emelunal@osmaniye.edu.tr
}

${ }^{1}$ https://orcid.org/0000-0002-0284-574X 


\section{Giriş}

Bugünlerde, sağlıkla ilgili özellikleri geliştirilmiş olan fonksiyonel gıda ürünlerinin tüketimine dair bir yönelim vardır. Probiyotik fonksiyonel bir gıda ürünü geliştirirken probiyotik bakteri seçimi, gıdanın bileşimi ve işleme koşullarını göz önünde bulundurmak gerekmektedir. Özelliklede probiyotik gıdalarda probiyotik hücre sayısının belli oranda tutulması zorunluluğu göz önünde bulundurulduğunda gerek gıdadan ve prosesten kaynaklı gerekse depolama koşullarından kaynaklı olumsuz koşullara dayanım elzemdir (Furtado ve ark., 2019). Probiyotik gidalardaki kültürlerin sağl1k üzerindeki yararlı etkilerinin görülebilmesi için yer aldığı gıda ürününde en az $10^{6} \mathrm{kob} / \mathrm{g}$ veya mL düzeyinde bulunması gerekmektedir (Randazzo ve ark., 2013; Terpou ve ark., 2019). Probiyotik mikroorganizmaların gıda bileşiminden kaynaklı stres faktörlerine, depolama koşullarına ve gastrik koşullara dayanım açısından mikroenkapsülasyon yöntemleri uygulanır. Mikroenkapsülasyon, hassas mikroorganizma hücresini bir kabuk gibi sararak dışarıdan gelen olumsuz çevre koşullarında hücre hasarını minimumda tutan bir işlemdir (Kalkan ve ark., 2018; 2020; Terpou ve ark., 2019). Probiyotik gıda üretiminde bilindiği üzere sıklıkla süt ürünlerine başvurulmuştur. Probiyotik gıdaların ağırlıklı olarak süt ürünlerinden oluştuğu düşünüldüğünde süt ürünlerini tüketmeyen bireylere yönelik yeni probiyotik gıdaların tasarlanması gerekliliği ortaya çıkmıştır. Süt ürünleri dışında; probiyotik kültür ilavesi ile üretilen gıdalara; elma suyu, portakal suyu, ananas suyu, limon suyu, şeftali suyu, kivi suyu, çilek suyu, kaju, nar suyu, tahıl ürünleri, tatlılar, mango suyu, gofret, çikolata, şekerkamışı suyu, kızılcık suyu, sucuk, sosis, vişne suyu gibi ürünler örnek olarak verilebilir (Espinazo ve Navaro, 2010; Antunes ve ark., 2013; Daneshi ve ark., 2013; Turhan ve ark., 2014; Alzate ve ark., 2016; Nematollahi ve ark., 2016; Furtado ve ark., 2019; Erginkaya ve ark., 2019). Bu ürün gruplarından özellikle de sebze ve meyve sularında probiyotik gıda denemeleri başarılı sonuçlar vermiştir (Randazzo ve ark., 2013; Nematollahi ve ark., 2016). Son yıllarda besinsel bileşimi ve sağlik üzerindeki olumlu etkileri vurgulanan keçiboynuzu pekmezi üzerinde durulmaya başlanmıştır (Toker ve ark., 2013). Gerek besleyici özellikleri gerekse yüksek enerji değeri ile keçiboynuzu pekmezi iyi bir probiyotik taşıyıcısı gıda olabilir.

Pekmez bileşiminde bulunan karbonhidrat, organik asit, protein, flavanoidler, fenolik maddeler, mineral madde (başlıca $\mathrm{K}, \mathrm{Ca}, \mathrm{Mg}, \mathrm{Na}, \mathrm{P}$ and $\mathrm{Fe}$ ) ve vitaminler bakımından besin değeri yüksek bir üründür ve insan sağlığı için faydalıdır (Aliyazıcıoğlu ve ark., 2009; Akkaya ve ark., 2012; Tounsi ve ark., 2017; 2019). Pekmez bileşimindeki bu maddelerin yani gıda matrisinin özellikleri probiyotik canlılığı üzerinde etkili olduğu için probiyotik keçiboynuzu pekmezi üretimini tasarlarken düşük su aktivitesi koşullarına dayanan ve depolama süresince ürünün kalite özellikleri üzerinde olumsuz etkisi olmayan probiyotik kültür uygulaması üzerinde durulması gerekmektedir. Gıda bileşiminden kaynaklı stres faktörlerine, depolama koşullarına ve gastrik koşullara dayanım açısından probiyotik 
kültürlerin mikroenkapsülasyonunu öneren birçok çalışma olmakla birlikte, farklı gıda ürünlerinde uygulanması ile ilgili çalışma sayısı sınırlıdır. Bu çalışmanın amacı; serbest ve mikroenkapsüle probiyotik kültürlerle keçiboynuzu pekmezi üretimi gerçekleştirmek ve depolama koşullarının probiyotik hücre canlılığı, $\mathrm{pH}$ ve duyusal özellikleri üzerindeki etkisi incelemektir.

\section{Materyal ve Metot}

$\mathrm{Bu}$ çalışmada sade $(\mathrm{K})$, mikroenkapsüle $(\mathrm{M})$ ve serbest probiyotik kültür $(\mathrm{S})$ içeren keçiboynuzu pekmezi üretimi (2 paralel ve 3 tekerrür) 3 farklı deneme planı (K, M ve S) ile gerçekleştirilmiştir. Keçiboynuzu pekmezlerinin fabrika tarafından önerilen depolama sıcaklığı oda sıcaklığıdır. Ancak, denemelerimizde keçiboynuzu pekmezlerine ilave edilen probiyotik kültürün oda sıcaklığında pekmezi fermente etme ve tadını bozma ihtimaline karşı iki farklı depolama sıcaklığı tercih edilmiştir. $\mathrm{Bu}$ bakımdan probiyotik ve sade keçiboynuzu pekmezleri $4^{\circ} \mathrm{C}$ ve $25^{\circ} \mathrm{C}$ de depolanmıştır. Depolama süresi pandemi dönemine denk geldiği için ve kısıtlamalardan ötürü 1 ay ile sınırlı tutulabilmiştir. Bu sebepten analizler başlangıç (0. gün) ve 30. gün'de alınan örnekler üzerinde gerçekleştirilmiştir.

\subsection{Probiyotik Kültür}

Probiyotik kültür olarak kullanılan Lactobacillus rhamnosus ise Danisco USA INC.'den temin edilmiştir. Probiyotik kültürlerin ilave edildiği keçiboynuzu pekmezleri Kadirli’de keçiboynuzu pekmezi üretimi yapan bir fabrikadan temin edilmiştir.

\subsection{Serbest ve Mikroenkapsüle Probiyotik Kültür Hazırlığı}

Stok kültürden alınan L. rhamnosus MRS (de Man, Rogosa, and Sharpe) broth (Merck, Germany) besiyeri içerisinde $37^{\circ} \mathrm{C}$ 'de 24 saat inkübasyona bırakılarak geliştirilmiş ve böylece serbest L. rhamnosus kültürü elde edilmiştir. Mikroenkapsüle probiyotik kültür eldesi için serbest $L$. rhamnosus kültürü ekstrüzyon tekniği ile mikroenkapsülasyona maruz bırakılmıştır (Chen ve ark., 2007). Kullanılan tüm cam malzemeler ve çözeltiler $121^{\circ} \mathrm{C}$ ' de 15 dakika süreyle sterilize edilmiştir. Kaplama materyali çözeltisi destile su kullanılarak hazırlanmıştır. $10^{9} \mathrm{kob} / \mathrm{mL}$ konsantrasyondaki probiyotik kültür (serbest L. rhamnosus kültürü) steril kaplama materyali çözeltisine (Aljinat-Merck) 1/5 oranında ilave edilmiştir. Probiyotik kültür içeren bu karışım $\left(10^{8} \mathrm{kob} / \mathrm{mL}\right) 0.11 \mathrm{~mm}$ 'lik iğnesi olan şırınga ile 0.05 M'lık steril CaCl2 (Merck-Germany) çözeltisi içerisine enjekte edilmiştir. Oluşan kapsüller, yeterli sertliği kazanmaları amacıyla 30 dakika süre ile çözelti içerisinde bırakılmış ve 
sonra "whatman $\neq 4$ filtre kâğıdı" (Merck) ile süzülerek kullanıma hazır hale gelmiştir (Şekil 1) (Erginkaya ve ark., 2019).

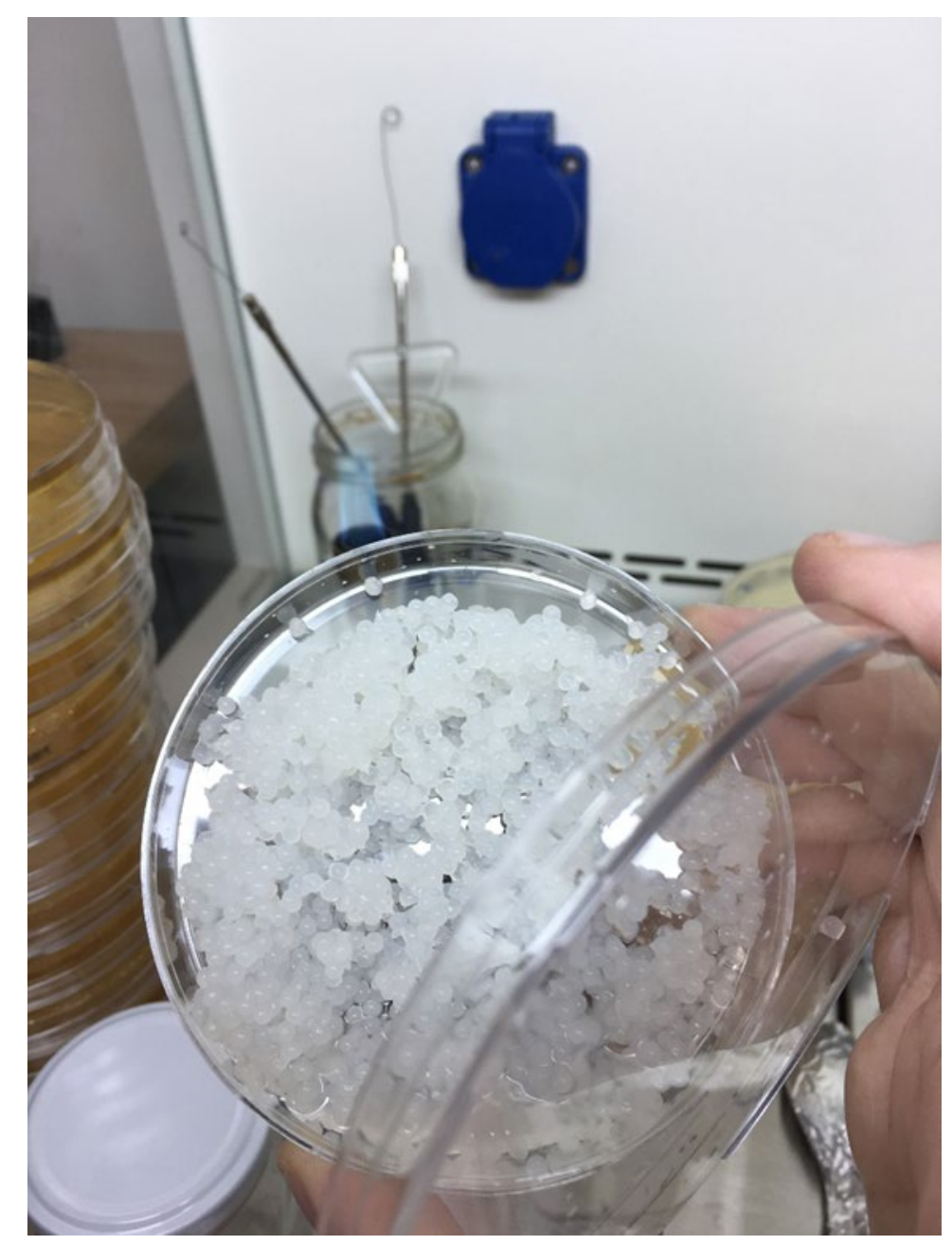

Şekil 1. Mikroenkapsüle L. rhamnosus

\subsection{Probiyotik Keçiboynuzu Pekmezi Üretimi}

$\mathrm{Bu}$ projede probiyotik keçiboynuzu pekmezi üretimleri; serbest probiyotik kültür (S) ve mikroenkapsüle probiyotik kültür ilaveli (M) olmak üzere iki farklı uygulama ile elde edilmiştir. Kontrol örneği olarak ise hiçbir probiyotik kültür ilavesi yapılmamış olan bütün üretimlerde kullanılmak üzere fabrikadan temin edilen sade keçiboynuzu pekmezleri değerlendirilmiştir. Sonuçta bu çalışmada sade $(\mathrm{K})$, serbest probiyotik kültürlü $(\mathrm{S})$ ve mikroenkapsüle probiyotik kültürlü $(\mathrm{M})$ olmak üzere 3 farklı örnek grubu üzerinde ilgili analizler yapılmıştır. Serbest probiyotik kültürlü keçiboynuzu pekmezi üretimi için; aseptik koşullar altında oda sıcaklığında $100 \mathrm{~mL}$ keçiboynuzu pekmezine $2 \mathrm{~mL}$ serbest L. rhamnosus (yaklaşı $10^{7} \mathrm{kob} / \mathrm{mL}$ ) ilave edilmiş ve ardından amber cam şişeler içinde kapakları kapatılarak ambalajlanmıştır. Mikroenkapsüle probiyotik kültürlü keçiboynuzu pekmezi üretimi için ise, aseptik koşullar altında oda sıcaklığında $100 \mathrm{~mL}$ keçiboynuzu 
pekmezine 2 gr mikroenkapsüle L. rhamnosus ilave edilmiş ve ardından amber cam şişeler içinde kapakları kapatılarak ambalajlanmıştır (Şekil 2).

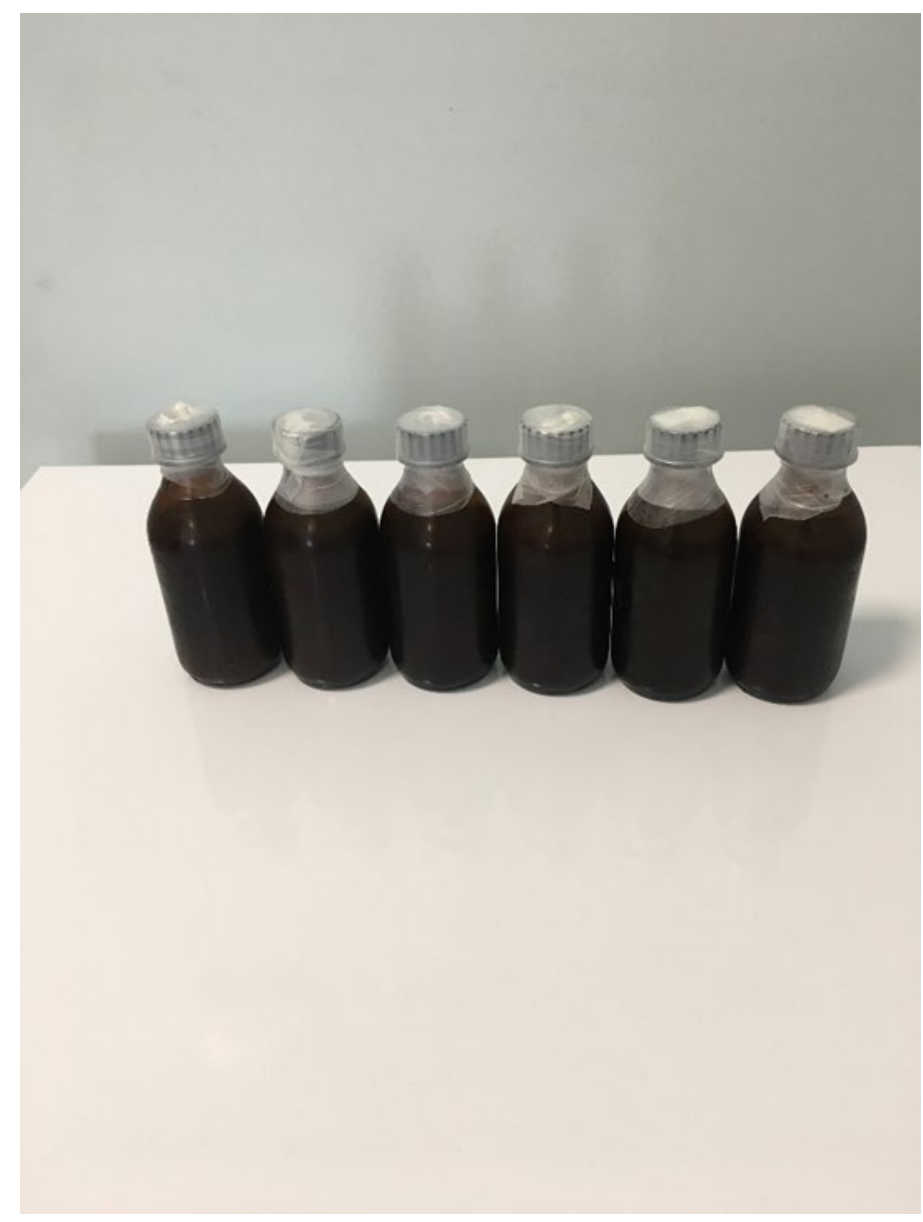

Şekil 2. Probiyotik keçiboynuzu pekmezleri

\subsection{Probiyotik Keçiboynuzu Pekmezlerindeki L. rhamnosus Sayısının Belirlenmesi}

L. rhamnosus sayımı için, $10 \mathrm{~g}$ keçiboynuzu pekmezi $90 \mathrm{~mL}$ steril dilüsyon sıvısı ile $(\% 0.85$ tuz ve \%0.1 pepton içeren) homojenize edilmiştir. Homojenize edilen örnekten $1 \mathrm{~mL}$ alınmış ve dilüsyon sıvısı kullanılarak seyreltilmiştir. Daha sonra $0.1 \mathrm{~mL}$ seyreltilmiş örnekler de Man, Rogosa Sharpe (MRS) agar'a (Merck-Germany) yayma ekim yöntemiyle ekilmiş ve $37^{\circ} \mathrm{C}$ 'de anaerobik koşullarda 48 saat inkübasyona bırakılmıştır (Halkman, 2005).

\section{2. pH Tayini}

pH tayini cam elektrotlu WTW marka pH metre kullanılarak oda koşullarında yapılmıştır (Cemeroğlu, 1992). 


\subsection{Duyusal Analiz}

Duyusal analizler 5 kişiden oluşan panelist tarafından gerçekleştirilmiştir. 3 ayrı keçiboynuzu pekmezi örneği daha önceki araştırmacılar tarafından önerilen duyusal özelliklere (renk, koku, kıvam, tat, genel kabul edilebilirlik) göre 1-9 puan üzerinden değerlendirilmiştir. Değerlendirmede 5 puan orta dereceyi göstermekte ve bu puanın altındaki değerler duyusal kalite açısından kötü, üzerindeki değerler duyusal kalite açısından iyi olarak nitelendirilmiştir. Sonuçta duyusal analizlerde elde edilen 5 puan bir ürünün red ve kabul kriteri olarak değerlendirilmiştir (Dimassi ve ark., 2019).

\subsection{4. İstatistiksel Analizler}

Elde edilen bulgular SPSS 20 paket programı (IBM SPSS Advanced Statistics 20.0-SPSS Inc, ABD) kullanılarak tek yönlü varyans analizine (ANOVA) tabi tutulmuş ve önemli bulunan farkl1lıklar Duncan çoklu karşılaştırma testine göre $(\mathrm{P}<0.05)$ değerlendirilmiştir (Özdamar, 1999).

\section{Bulgular ve Tartışma}

Bu çalışmada probiyotik keçiboynuzu pekmezi üretimi tasarlanırken, probiyotik kültürlerin gıda matrisinden kaynaklı stres faktörlerine dayanması ve depolama süresince ürünün kalite özellikleri üzerinde olumsuz etkisi olmaması hedeflenmiştir. Bu kapsamda keçiboynuzu pekmezi örneklerindeki probiyotik canlı hücre sayısı, pH ve duyusal özellikler incelenmiştir.

Gıda bileşiminden kaynaklı stres faktörlerine, depolama koşullarına ve gastrik koşullara dayanım açısından probiyotik kültürlerin mikroenkapsülasyonunu öneren birçok çalışma mevcuttur. Şimdiye kadar yapılan çalışmalarda gerek süt ürünlerinde gerekse meyve-sebze ürünlerinde ağırlıklı olarak L. rhamnosus kullanılmış ve başarılı sonuçlar verdiği bildirilmiştir (Sheehan ve ark., 2007; Shah ve rk., 2010; Sohail ve ark., 2012; Ying ve ark., 2013). Nitekim, bu projede de probiyotik keçiboynuzu formülasyonunda stres faktörlerine karşı dayanımı arttırmak için mikroenkapsüle $L$. rhamnosus kullanımı tercih edilmiştir. Tablo 1'de farklı yöntemlerle elde edilen keçiboynuzu pekmezlerinde farklı sıcaklıklarda depolamanın L. rhamnosus sayısı üzerindeki etkisi gösterilmiştir. 
Tablo 1. Keçiboynuzu pekmezi örneklerindeki canlı L. rhamnosus sayısı

\begin{tabular}{cccc}
\hline Örnekler & 0. Gün & 30. Gün $\left(4^{\circ} C\right)$ & 30. Gün $\left(25^{\circ} C\right)$ \\
\hline$M$ & $7.16 \pm 0.12^{\mathrm{bA}}$ & $7.64 \pm 0.09^{\mathrm{cB}}$ & $7.79 \pm 0.32^{\mathrm{cB}}$ \\
$\mathrm{S}$ & $7.25 \pm 0.06^{\mathrm{bA}}$ & $7.28 \pm 0.12^{\mathrm{bA}}$ & $7.31 \pm 0.18^{\mathrm{bA}}$ \\
$\mathrm{K}$ & $0.00 \pm 0.00^{\mathrm{aA}}$ & $0.00 \pm 0.00^{\mathrm{aA}}$ & $0.00 \pm 0.00^{\mathrm{aA}}$ \\
\hline
\end{tabular}

M: Mikroenkapsüle probiyotik kültür içeren pekmez, S: Serbest probiyotik kültür içeren pekmez, K: Probiyotik kültür içermeyen sade pekmez (Kontrol örneği). A, B, C: Aynı satır içerisinde farklı harflerle gösterilen ortalamalar arasındaki fark istatistiksel olarak önemlidir. ( $\mathrm{P}<0.05)$; $\mathrm{a}, \mathrm{b}, \mathrm{c}$ : Aynı sütun içerisinde farklı harflerle gösterilen ortalamalar arasındaki fark istatistiksel olarak önemlidir $(\mathrm{P}<0.05)$

Tablo 1'de de görüldüğü gibi, pekmez örneklerindeki L. rhamnosus sayısı üzerinde mikroenkapsülasyon işleminin etkisi önemli bulunurken, depolama sıcaklığının etkisi önemsiz bulunmuştur. Mikroenkapsüle probiyotik kültürlerin bulunduğu keçiboynuzu pekmezlerinde hücre canlılı̆̆1 (en fazla $7.79 \log \mathrm{kob} / \mathrm{mL}$ ) serbest kültür bulunan örneklerdekinden (en fazla $7.31 \log$ $\mathrm{kob} / \mathrm{mL}$ ) daha yüksek bulunmuştur. $\mathrm{Bu}$ durum literatür çalışmalarında vurgulanan, mikroenkapsülasyonun probiyotikleri olumsuz çevre koşullarına karşı koruduğu hipotezini desteklemiştir (Prado ve ark., 2008; Sohail ve ark., 2012; Perricone ve ark., 2015). Çalışmamızda farklı sıcaklıklarda depolamanın probiyotik hücre canlılığı üzerinde istatistiksel olarak önemli bir etkisinin olmadığı görülmüştür. 30 günlük depolama süresinin probiyotik canlılığı üzerindeki etkisi ise, mikroenkapsüle kültürlerin kullanıldığ 1 örnekler için önemli bulunurken serbest kültürlerin kullanıldığı örneklerde önemsiz bulunmuştur. Mikroenkapsüle probiyotik kültürlerin kullanıldığ pekmezlerde 30 günlük depolamanın sonunda canlı hücre sayısının başlangıçtaki miktarlarına göre yükseldiği gözlenmiştir. Çalışma sonuçlarımızla benzer olarak, önceki çalışmalarda bazı araştırmacılar elma, portakal ve nar suyu gibi meyve sularına mikroenkapsüle/serbest probiyotik kültür (Lactobacillus rhamnosus, Bifidobacterium longum, L. salivarius, L. plantarum, L. acidophilus, L. paracasei, B. lactis) ilave etmişler ve mikroenkapsüle kültürlerin depolama dayanımlarının serbest kültürlerden daha iyi olduğunu bildirmişlerdir (Ding ve Shah, 2008; Nualkaekul ve ark., 2013, Ying ve ark., 2013). Antunes ve ark., (2013) tropik bir meyve olan "acerola" nektarında probiyotik uygulanması ile ilgili çalışmalarında; asidik koşullar başta olmak üzere meyve suyu bileşiminden kaynaklı stres faktörlerine karşı probiyotik kültür uygulamasında mikroenkapsülasyonun hücre canlılı̆̆ını korumak açısından iyi bir yöntem olduğunu ortaya çıkarmıştır.

Farklı yöntemlerle elde edilen keçiboynuzu pekmezlerinde farklı sıcaklıklarda depolamanın pH değerleri üzerindeki etkisi Tablo 2'de gösterilmiştir. Pekmez örneklerindeki pH değeri üzerinde mikroenkapsülasyon işleminin ve depolama sıcaklığının etkisi önemsiz bulunurken, depolama süresinin etkisi istatistiksel olarak önemli bulunmuştur. Bu durum kısa süreli depolamalarda mikroenkapsüle kültür kullanmakla serbest kültür kullanmak arasında probiyotik stabilitesi açısından bir fark olmadığını göstermiştir. Ancak uzun süreli depolamalarda mikroenkapsülasyonun koruyucu 
etkisinin olması muhtemeldir. Bu yüzden ilerleyen çalışmalarda daha uzun süreli depolamanın etkisi üzerinde durulması önerilir.

Tablo 2. Keçiboynuzu pekmezi örneklerinin pH değerleri

\begin{tabular}{cccc}
\hline Örnekler & 0. Gün & 30. Gün $\left(4^{\circ} C\right)$ & 30. Gün $\left(25^{\circ} C\right)$ \\
\hline$M$ & $5.47 \pm 0.01^{\mathrm{aB}}$ & $5.34^{*} \pm 0.02^{\mathrm{aA}}$ & $5.29^{*} \pm 0.02^{\mathrm{aA}}$ \\
$\mathrm{S}$ & $5.48 \pm 0.01^{\mathrm{aB}}$ & $5.38^{*} \pm 0.01^{\mathrm{aA}}$ & $5.34^{*} \pm 0.02^{\mathrm{aA}}$ \\
$\mathrm{K}$ & $5.52 \pm 0.02^{\mathrm{bA}}$ & $5.50 \pm 0.02^{\mathrm{bA}}$ & $5.51 \pm 0.02^{\mathrm{bA}}$ \\
\hline
\end{tabular}

M: Mikroenkapsüle probiyotik kültür içeren pekmez, S: Serbest probiyotik kültür içeren pekmez, K: Probiyotik kültür içermeyen sade pekmez (Kontrol örneği). A, B, C: Aynı satır içerisinde farklı harflerle gösterilen ortalamalar arasındaki fark istatistiksel olarak önemlidir $(\mathrm{P}<0.05)$; a, b, c: Aynı sütun içerisinde farklı harflerle gösterilen ortalamalar arasındaki fark istatistiksel olarak önemlidir $(\mathrm{P}<0.05)$

Farklı yöntemlerle elde edilen keçiboynuzu pekmezlerinde farklı sıcaklıklarda depolamanın bazı duyusal kalite özellikleri üzerindeki etkisi Tablo 3'de gösterilmiştir.

Tablo 3. Keçiboynuzu pekmezi örneklerinin bazı duyusal özellikleri

\begin{tabular}{ccccc}
\hline Duyusal Özellik & Örnekler & $0 . G u ̈ n$ & $30 . G u ̈ n\left(4{ }^{\circ} C\right)$ & $30 . G u ̈ n\left(25^{\circ} C\right)$ \\
\hline \multirow{2}{*}{ Renk } & M & $9.33 \pm 0.58^{\mathrm{aB}}$ & $8.67 \pm 0.58^{\mathrm{aB}}$ & $7.33^{*} \pm 0.58^{\mathrm{aA}}$ \\
& $\mathrm{S}$ & $9.33 \pm 0.58^{\mathrm{aA}}$ & $8.67 \pm 0.58^{\mathrm{aA}}$ & $8.33 \pm 0.58^{\mathrm{bA}}$ \\
& $\mathrm{K}$ & $10.00 \pm 0.00^{\mathrm{bA}}$ & $9.67 \pm 0.58^{\mathrm{bA}}$ & $9.33 \pm 0.58^{\mathrm{cA}}$ \\
\hline \multirow{2}{*}{ Koku } & $\mathrm{M}$ & $10.00 \pm 0.00^{\mathrm{aB}}$ & $9.67 \pm 0.58^{\mathrm{aB}}$ & $8.33^{*} \pm 0.58^{\mathrm{aA}}$ \\
& $\mathrm{S}$ & $10.00 \pm 0.00^{\mathrm{aB}}$ & $9.67 \pm 0.58^{\mathrm{aB}}$ & $8.67^{*} \pm 0.58^{\mathrm{aA}}$ \\
& $\mathrm{K}$ & $10.00 \pm 0.00^{\mathrm{aA}}$ & $9.67 \pm 0.58^{\mathrm{aA}}$ & $9.67 \pm 0.58^{\mathrm{bA}}$ \\
\hline \multirow{2}{*}{ Kivam } & $\mathrm{M}$ & $8.67 \pm 0.58^{\mathrm{aB}}$ & $8.33 \pm 0.58^{\mathrm{aB}}$ & $7.33^{*} \pm 0.58^{\mathrm{aA}}$ \\
& $\mathrm{S}$ & $10.00 \pm 0.00^{\mathrm{bB}}$ & $9.33^{*} \pm 0.58^{\mathrm{bA}}$ & $9.33^{*} \pm 0.58^{\mathrm{bA}}$ \\
& $\mathrm{K}$ & $10.00 \pm 0.00^{\mathrm{bA}}$ & $9.67 \pm 0.58^{\mathrm{bA}}$ & $9.67 \pm 0.58^{\mathrm{bA}}$ \\
\hline \multirow{2}{*}{ Tat } & $\mathrm{M}$ & $9.33 \pm 0.58^{\mathrm{aB}}$ & $8.67 \pm 0.58^{\mathrm{aB}}$ & $7.67^{*} \pm 0.58^{\mathrm{aA}}$ \\
& $\mathrm{S}$ & $10.00 \pm 0.00^{\mathrm{bB}}$ & $8.67^{*} \pm 0.58^{\mathrm{aA}}$ & $8.67^{*} \pm 0.58^{\mathrm{bA}}$ \\
& $\mathrm{K}$ & $10.00 \pm 0.00^{\mathrm{bB}}$ & $9.67 \pm 0.58^{\mathrm{bA}}$ & $9.67 \pm 0.58^{\mathrm{cA}}$ \\
\hline \multirow{2}{*}{ Genel Kabul Edilebilirlik } & $\mathrm{M}$ & $9.00 \pm 0.58^{\mathrm{aB}}$ & $8.67 \pm 0.58^{\mathrm{aB}}$ & $7.67^{*} \pm 0.58^{\mathrm{aA}}$ \\
& $\mathrm{S}$ & $10.00 \pm 0.00^{\mathrm{bB}}$ & $9.33 \pm 0.58^{\mathrm{bB}}$ & $8.33^{*} \pm 0.58^{\mathrm{bA}}$ \\
& $\mathrm{K}$ & $10.00 \pm 0.00^{\mathrm{bB}}$ & $9.67 \pm 0.58^{\mathrm{cB}}$ & $8.67^{*} \pm 0.58^{\mathrm{cA}}$ \\
\hline
\end{tabular}

M: Mikroenkapsüle probiyotik kültür içeren pekmez, S: Serbest probiyotik kültür içeren pekmez, K: Probiyotik kültür içermeyen sade pekmez (Kontrol örneği). A, B, C: Aynı satır içerisinde farklı harflerle gösterilen ortalamalar arasındaki fark istatistiksel olarak önemlidir $(\mathrm{P}<0.05)$; a, b, c: Aynı sütun içerisinde her bir duyusal özellik için farklı harflerle gösterilen ortalamalar arasındaki fark istatistiksel olarak önemlidir $(\mathrm{P}<0.05)$

Duyusal kalite özellikleri açısından mikroenkapsüle kültür kullanılan pekmezler çoğunlukla daha az beğenilmiş ve mikroenkaspülasyon işleminin etkisi istatistiksel olarak önemli bulunmuştur. Özelliklede kıvam ve tat özellikleri açısından mikroenkapsüle kültür içeren pekmezler daha az beğenilmiştir. $\mathrm{Bu}$ durumun probiyotik kültürlerin hapsedildiği küçük boncuklar şeklindeki kapsüllerin pekmezde kıvam ve tat özellikleri açısından fark edilir olduğunu göstermiştir. Benzer 
olarak, Krasaekoopt ve Kitswad (2010) tarafindan meyve sularında mikroenkapsüle probiyotik kültür kullanımının duyusal özellikler bakımından ürünün kabulüne dair tüketici davranışı üzerindeki etkisini inceleyen bir çalışma yapılmıştır. Bu araştırmacıların çalışmasında meyve suyu gibi akışkan bir gıdada probiyotik mikrokapsül varlığının özellikle "meyve suyunu yutma" esnasında tüketici üzerinde olumsuz izlenim bıraktı̆̆ı sonucuna varılmıştır.

Depolama sıcaklığının etkisine bakıldığında ise $25^{\circ} \mathrm{C}$ 'de depolanan örneklerin daha düşük puanlar aldığı ve bu farkın istatistiksel olarak önemli olduğu bulunmuştur. Çalışmada en beğenilen örnekler (8.67-10.00 puan) genellikle hiç bir probiyotük kültür ilavesi yapılmayan kontrol örnekleri olmuş, ancak probiyotik kültür ilavesi yapılan diğer örneklerde iyi puanlar (7.33-10.00 puan) alarak beğenilmiştir. Bu çalışmada sade keçiboynuzu pekmezlerine alternatif olarak probiyotik kültür ilavesi ile fonksiyonel özellik kazandırılan probiyotik keçiboynuzu pekmezlerinde kritik duyusal kabul edilebilirlik sınır değeri olan " 5 "in altına düşülmemiştir. Bu sebeple, çalışmada gerek serbest kültür kullanımı gerekse mikroenkapsüle kültür kullanımı ile üretilen yeni bir ürün olan probiyotik keçiboynuzu pekmezlerinin yüksek duyusal kabul edilebilirlik puanları ile sağlıklı gıda tüketimi eğilimindeki tüketicilere iyi bir alternatif yaratılmıştır.

Oda sıcaklığg koşullarında probiyotik kültürün keçiboynuzu bileşiminde bulunan maddeleri parçalaması yani metabolize etmesi sonucu ürünün duyusal ve fizikokimyasal özellikleri değişebilir. $\mathrm{Bu}$ açıdan depolama sıcaklığı olarak buzdolabı koşullarında depolamanın daha elverişli olacağı bildirilmiştir (Sheehan ve ark., 2007). Çalışmamızda bu literatür bilgileri ışığında oda sıcaklığının yanısıra $+4^{\circ} \mathrm{C}$ 'de depolama yöntemine de başvurulmuştur. Nitekim Sohail ve ark., (2012) mikroenkapsüle probiyotik kültür kullanımı ile ürettikleri meyve sularında iki farklı sıcaklıkta $\left(25^{\circ} \mathrm{C}\right.$ ve $4^{\circ} \mathrm{C}$ 'de) depolamanın asidifikasyon üzerindeki etkisini incelemişler ve çalışma sonucunda gerek mikroenkapsülasyonun gerekse buzdolabı koşullarında depolamanın asidifikasyonu geciktirdiğini saptamışlardır. Probiyotik kültürlerin mikroenkapsüle edilmesi gıda ortamı içinde salınımlarını ve gıda bileşenlerini parçalama etkilerini azaltır. Kısacası, ürün kalite özelliklerinin korunması bakımından buzdolabı sıcaklığında depolamanın faydalı olacağı bildirilmiştir (Randazzo ve ark., 2013; Patel, 2008).

\section{Sonuçlar ve Öneriler}

$\mathrm{Bu}$ çalışma ile besleyici değeri yüksek olan keçiboynuzu pekmezine probiyotik kültür ilavesi ile fonksiyonel özellik kazandırılmıştır. Probiyotik kültürlerin keçiboynuzu pekmezi gibi düşük su aktivitesi olan bir ortamda canlılıklarını korumaları ve tüketimden sonra gastrik koşullarda da dayanımlarının sağlanabilmesi açısından mikroenkapsüle edilerek ürüne ilave edilmesi kalite özellikleri açısından da olumlu sonuçlar vermiştir. Ancak farklı enkapsülasyon yöntemleri ve 
kaplama materyalleri denenerek ürünün duyusal açıdan kabul edilebilirliği daha da arttırılabilir. Çalışmanın süt ürünleri dışındaki probiyotik ürün çeşitliliğini arttırmak açısından gıda sanayiine fayda sağlayacağı düşünülmüş ve bu şekilde hem tüketici hem de sanayinin ihtiyaç duyduğu alternatif bir probiyotik ürün ortaya çıkarılmıştır. İlerleyen çalışmalarda probiyotik keçiboynuzu üretiminde kullanılan yöntemlerin daha uzun süreli depolamada ürün kalite özellikleri üzerindeki etkisinin incelenmesi önerilir. Ayrıca probiyotik kültürlerin metabolik aktivitesinden kaynaklı olarak keçiboynuzu pekmezlerinde sadece $\mathrm{pH}$ ve duyusal özellikler değil yanı sıra indirgen şeker, organik asit bileşimi, reolojik özellikler vb. gibi önemli kalite kriterleri de incelenmelidir.

\section{Araştırma ve Yayın Etiği Beyanı}

Yapılan çalışmada araştırma ve yayın etiğine uyulmuştur.

\section{Kaynaklar}

Akkaya, Z., Schröder, J., Tavman, Ş.,Kumcuoglu, S., Schuchmann, H.P., and Gaukel, V., (2012). Effects of spray drying on physical properties, total phenolic content and antioxidant activity of carob molasses. International Journal of Food Engineering, 8(4), 1-15.

Alzate, B.C.S., Rodriguez, M.C., and Campuzano, O.M., (2016). Identifcation of some kefr microorganisms and optimization of their production in sugarcane juice. Revista Facultad Nacional de Agronomia, 69(1), 7935-7943

Aliyazıcıŏlu, R., Kolaylı, S., Kara, M., Yıldız, O., Sarıkaya, A.O., Cengiz, S., and Er, F., (2009). Determination of chemical, physical and biological characteristics of some pekmez (molasses) from Turkey. Asian Journal of Chemistry, 21(3), 2215-2223.

Antunes, A.E.C., Liserre, A.M., Coelho, A.L.A., Menezes, C.R., Moreno, I., Yotsuyanagi, K., and Azambuja, N.C., (2013). Acerola nectar with added microencapsulated probiotic. LWT-Food Science and Technology, 54, 125-131.

Cemeroğlu, B., (1992). Meyve ve sebze işleme endüstrisinde temel analiz metotlart. Ankara: Biltav Yayınları.

Chen, M., Chen, K., and Kuo, Y. (2007). Optimal thermotolerance of Bifidobacterium bifidum in gellanalginate microparticles. Biotechnol Bioeng, 98 (2), 411-419.

Daneshi, M., Ehsani, M.R., Razavi, S.H., and Labbafi, M., (2013). Effect of refrigerated storage on the probiotic survival and sensory properties of milk/carrot juice mix drink. Electronic Journal of Biotechnology, 16(5), 1-12.

Dimassi, O., Khalife, R., Akiki, R., and Rached, M., (2019). Effect of different soaking media on the efficiency of carob molasses production. International Journal of Environment, Agriculture and Biotechnology, 4(3), 829-834.

Ding, W.K., and Shah, N.P., (2008). Survival of free and microencapsulated probiotic bacteria in orange and apple juices. International Food Research Journal, 15(2), 219-232.

Espinazo, Y.R., and Navaro, Y.G., (2010). Non-dairy probiotic products. Food Microbiology, 27, 1-11.

Erginkaya, Z., Sarıkodal, E., Özkütük, S.T., Konuray, G., and Ünal Turhan, E., (2019). Probiyotik bitter çikolata üretiminde mikroenkapsüle Lactobacillus rhamnosus kullanımı. Glda, 44(2), 238-247.

Furtado, L.L., Martins, M.L., Ramos, A.M., Silva, R.R., Junior, B.R.C.L, and Martins, E.M.F., (2019). Viability of probiotic bacteria in tropical mango juice and the resistance of the strains to gastrointestinal conditions simulated in vitro. Semina: Ciências Agrárias, Londrina, 4(1), 149-162.

Halkman, K., (2005). Merck gıda mikrobiyolojisi uygulamaları. Ankara, Türkiye: Başak Matbaacılık Limited Şti., 358s. 
Kalkan, S., Öztürk, D., Selimoğlu, and B.S., (2018). Determining some of the quality characteristics of probiotic yogurts manufactured by using microencapsulated Saccharomyces cerevisiae var. boulardii. Turk J Vet Anim Sci, 42, 617-623.

Kalkan, S., Otağ, M.R., Köksal, E.İ, Bozkurt, and N.Ş., (2020). Production of functional Turkish noodle (Erişte) supplementary probiotic and determining of some quality properties. Food and Health, 6(3), 140-150.

Krasaekoopt, W., and Kitsawad, K., (2010). Sensory characteristics and consumer acceptance of fruit juice containing probioitcs beads in Thailand. AU J.T., 14(1), 33-38.

Nematollahi, A., Sohrabvandi, S., Martazavian, A.M., and Jazaeri, S., (2016). Viability of probiotic bacteria and some chemical and sensory characteristics in cornelian cherry juice during cold storage. Electronic Journal of Biotechnology, 21, 49-53.

Nualkaekul, S., Cook, M.T., Khutoryanskiy, V.V., and Charalampopoulos, D., (2013). Influence of encapsulation and coating materials on the survival of Lactobacillus plantarum and Bifidobacterium longum in fruit juices. Food Research International, 53, 304-311.

Özdamar, K., (1999). Paket programlar ile istatistiksel veri analizi. Eskişehir, Türkiye: Kaan Kitabevi, 535s.

Patel, P., Parekh, T., and Subhash, R., (2008). Development of probiotic and synbiotic chocolate mousse: a functional food. Biotechnology, 7(4): 769-774.

Perricone, M., Bevilacqua, A., Altieri, C., Sinigaglia, M., and Corbo, M.R., (2015). Challenges for the production of probiotic fruit juices. Beverages, 1, 95-103.

Prado, Parada, J.L., Pandey, A., Soccol, C.R., (2008). Trends in non-dairy probiotic beverages. Food Research International, 41, 111-123.

Randazzo, C.L., Pitino, I., Licciardello, F., Muratore, G., and Caggia, C., (2013). Survival of Lactobacillus rhamnosus probiotic strains in peach jam during storage at different temperatures. Food Sci Technol Campinas, 33(4), 652-659.

Shah, N.P., Ding, W.K., Fallourd, M.J., and Leyer, G., (2010). Improving the stability of probiotic bacteria in model fruit juices using vitamins and antioxidants. Journal of Food Science, 75(5), 278-282.

Sheehan, V.M., Ross, P., and Fitzgerald, G.F., (2007). Assessing the acid tolerance and the technological robustness of probiotic cultures for fortification in fruit juices. Innovative Food Science and Emerging Technologies, 8, 279-284.

Sohail, A., Turner, M.S., Prabawati, E.K., Coombes,A.G.A., and Bhandari, B., (2012). Evaluation of Lactobacillus rhamnosus GG and Lactobacillus acidophilus NCFM encapsulated using a novel impinging aerosol method in fruit food products. International Journal of Food Microbiology, 157, 162166.

Terpou, A, Papadaki, A., Lappa, I.K., Kachrimanidou, V., Bosnea, L.A., and Kopsahelis, N., (2019). Probiotics in food systems: significance and emerging strategies towards improved viability and delivery of enhanced beneficial value. Nutrients, 11, 1-32.

Toker, O.S., Dogan, M., Ersöz, N.B., and Yilmaz, M.T., (2013). Optimization of the content of 5hydroxymethylfurfural (HMF) formed in some molasses types: HPLC-DAD analysis to determine effect of different storage time and temperature levels. Industrial Crops and Products, 50, 137-144.

Tounsi, L., Karra, S., Kechaou, H., and Kechaou, N., (2017). Processing, physico-chemical and functional properties of carob molasses and powders. Food Measurement, 11, 1440-1448.

Tounsi, L., Ghazala, I., and Kechaou, N., (2019). Physicochemical and phytochemical properties of Tunisian carob molasses. Journal of Food Measurement and Characterization, 14, 20-30.

Turhan, E.U, Erginkaya, Z., Polat, S., and Özer, E.A., (2014). Design of probiotic dry fermented sausage (sucuk) production with microencapsulated and free cells of Lactobacillus rhamnosus. Turk J Vet Anim Sci, 41, 598-603.

Ying, D., Schwander, S., Weerakkody, R., Sanguansri, L., Gantenbein-Demarchi, C., and Augustin, M.A., (2013). Microencapsulated Lactobacillus rhamnosus GG in whey protein and resistant starch matrices: Probiotic survival in fruit juice. Journal of Functional Foods 5, 98-105. 